\title{
Physiological attributes of jatropha under different planting densities and nitrogen doses
}

\author{
Allan R. F. Campos ${ }^{1}$, Rosiane L. S. de Lima², Carlos A. V. de Azevedo², \\ Ronaldo do Nascimento ${ }^{2} \&$ Sonivagno S. Silva ${ }^{3}$ \\ ${ }^{1}$ Universidade Federal do Recôncavo da Bahia/Centro de Ciências Agrárias, Ambientais e Biológica/Programa de Pós-Graduação em Engenharia Agrícola. \\ Cruz das Almas, BA. E-mail: allanradax@hotmail.com (Corresponding author) \\ ${ }^{2}$ Universidade Federal de Campina Grande/Centro de Tecnologia e Recursos Naturais/Unidade Acadêmica de Engenharia Agrícola. Campina Grande, PB. \\ E-mail: limarosiane@yahoo.com.br; cvieiradeazevedo@gmail.com; ronaldo@deag.ufcg.edu.br \\ ${ }^{3}$ Universidade Federal de Campina Grande/Centro de Tecnologia e Recursos Naturais/Pós-Graduação em Engenharia Agrícola. Campina Grande, PB. \\ E-mail: sonyvagno@yahoo.com.br
}

\section{Key words:}

Jatropha curcas

gas exchange nitrogen fertilizer

water use efficiency

\begin{abstract}
A B S T R A C T
Nitrogen $(\mathrm{N})$ fertilization associated with planting density is a practice that can improve the physiological aspects and consequently increase the yield of a crop. Thus, this study aimed to evaluate the effects of planting density and $\mathrm{N}$ levels on the physiological aspects of jatropha in the 'Agreste' region of Paraíba. Treatments consisted of four planting densities (833, 1,111, 1,666 and 2,500 plants $\left.\mathrm{ha}^{-1}\right)$ representing the plots and five $\mathrm{N}$ doses $(0,40$, 80,120 and $180 \mathrm{~kg} \mathrm{ha}^{-1}$ ) corresponding the subplots. The effects of treatments on $\mathrm{CO}_{2}$ assimilation rate, internal $\mathrm{CO}_{2}$ concentration, transpiration, stomatal conductance, water use efficiency, instantaneous carboxylation efficiency and SPAD index were analysed. Except for stomatal conductance, the other variables were influenced by the interaction between planting densities and $\mathrm{N}$ levels. The association of the dose of $80 \mathrm{~kg} \mathrm{ha}^{-1}$ with a planting density of 2,200 plants ha-1 provided adequate conditions for the production of plants with increased photosynthetic activity and efficient use of water.
\end{abstract}

\section{Palavras-chave: Jatropha curcas trocas gasosas fertilizante nitrogenado eficiência do uso da água}

\section{Aspectos fisiológicos do pinhão-manso sob diferentes densidades de plantio e doses de nitrogênio}

\begin{abstract}
R E S U M O
A adubação nitrogenada associada à densidade de plantio é uma prática que pode melhorar os aspectos fisiológicos e, consequentemente, aumentar os rendimentos de uma cultura. Deste modo o presente trabalho teve, como objetivo, avaliar os efeitos da densidade de plantio e de doses de nitrogênio nos aspectos fisiológicos do pinhão-manso, na região do Agreste Paraibano. Os tratamentos consistiram de quatro densidades de plantio de 833, $1.111,1.666$ e 2.500 plantas $\mathrm{ha}^{-1}$, representando as parcelas e cinco doses de nitrogênio de $0,40,80,120$ e $180 \mathrm{~kg} \mathrm{ha}^{-1}$, representando as subparcelas. Foram analisados os efeitos sobre a taxa de assimilação de $\mathrm{CO}_{2}$, concentração interna de $\mathrm{CO}_{2}$, transpiração, condutância estomática, eficiência no uso da água, eficiência intrínseca da carboxilação e índice SPAD. Exceto a condutância estomática, as demais variáveis foram influenciadas pela interação entre as densidades de plantio e as doses de nitrogênio; a associação da dose de $80 \mathrm{~kg} \mathrm{ha}^{-1}$

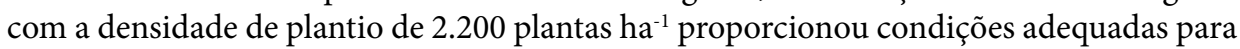
a obtenção de plantas com maior atividade fotossintética e uso eficiente da água.
\end{abstract}




\section{INTRODUCTION}

Jatropha (Jatropha curcas L.) has been indicated as a promising alternative for the supply of oil aiming at the production of biodiesel in various countries, such as Mexico, Nicaragua, Thailand and parts of India, besides Brazil (Bangzhen \& Zengfu, 2011; Laviola et al., 2012). Studies involving the strategy of absorption of mineral nutrients by plants deserve special attention in the case of nitrogen $(\mathrm{N})$, whose assimilation is essential for plant metabolism, as a whole, since this nutrient participates in chlorophyll molecules, nitrogenous bases, amino acids and is directly associated with leaf expansion and better responses in the photosynthetic rates (Sousa et al., 2012; Brito et al., 2014). Some studies have been conducted regarding the fertilization of jatropha (Akbarian et al., 2010; Mohapatra \& Panda, 2011; Simões et al., 2014; Freiberger et al., 2015).

For the $\mathrm{N}$ fertilization of jatropha, Mohapatra \& Panda (2011) recommend the application of $60 \mathrm{~g}^{\text {of }} \mathrm{N} \mathrm{plant}^{-1}$ in plantations more than six years old. On the other hand, Akbarian et al. (2010) suggest the application of $70 \mathrm{~kg} \mathrm{ha}^{-1}$ of $\mathrm{N}$ in adult jatropha plantations distributed at spacing of $2 \times 2 \mathrm{~m}$. The available spacing recommendations for the crop are almost exclusively based on those established for other crops, which may cause the system to show low production. According to the literature, denser plantations increase the yield of jatropha plants (Akbarian et al., 2010; Horschutz et al., 2012; Sharma, 2012).

Despite the various indications of fertilization for the jatropha crop under field and greenhouse conditions, field data that serve as a support are still scarce, especially associated with different planting densities. In this context, this study aimed to evaluate the physiological aspects of jatropha as a function of the different planting configurations and $\mathrm{N}$ doses, in the 'Agreste' region of the Paraíba state.

\section{Material ANd Methods}

The experiment was carried out from June to December 2014, at the field, under rainfed regime, at the experimental station of the Agricultural Research Company of the state of Paraíba (EMEPA), located in the municipality of Lagoa Seca$\mathrm{PB}$, 'Agreste' region of Paraíba, Brazil (7 9' 28' S; $35^{\circ} 52^{\prime} 24^{\prime}$ ' W; $630 \mathrm{~m}$ ). According to Köppen's classification, the region has rainy tropical climate with dry season in the summer (Figure 1).

The experiment was installed in randomized blocks with four replicates using a $4 \times 5$ factorial scheme in split plots, corresponding to the planting densities of $833,1,111,1,666$ and 2,500 plants ha ${ }^{-1}$ as the plots and $\mathrm{N}$ doses of $0,40,80,120$ and $180 \mathrm{~kg} \mathrm{ha}^{-1}$ as the subplots, which were applied in the form of ammonium sulfate, according to the spacings.

Each plot had dimensions of $16 \times 16 \mathrm{~m}$ varied from 4 rows with 5 plants to 7 rows with 7 plants. The densest plots were formed by 49 plants and the least dense ones by 20 plants each. Evaluations were performed considering an area with 5 plants of each plot. The $\mathrm{N}$ doses per plant were calculated based on the planting density, distributed as top-dressing fertilization, split into levels of 40,30 and $30 \%$ of the dose. The first one was applied at 15 months of age after pruning and the second and third ones, respectively, at 30 and 60 days after the first fertilization. The phosphorus and potassium (PK) fertilization consisted in the doses of 90 and $60 \mathrm{~kg} \mathrm{ha}^{-1}$ of triple superphosphate and potassium chloride, $100 \%$ as basal fertilization in the area under the canopy projection at the depth of $20 \mathrm{~cm}$ (Brito et al., 2014).

The experiment was installed and conducted during the second cycle of the jatropha crop at 15 months of age in a soil with sandy loam texture (Table 1).

In order to start the experiment and study the effects of $\mathrm{N}$ doses and planting densities in the month of June, a drastic pruning was performed, which consisted in the total removal of the shoots at a height of $80 \mathrm{~cm}$, to standardize the experimental area. The cultivation practices relative to the control of plants that compete for water and nutrients, and pests and diseases were performed according to the necessity.

The physiological variables were analyzed at the beginning of the reproductive stage (flowering). Gas exchanges were

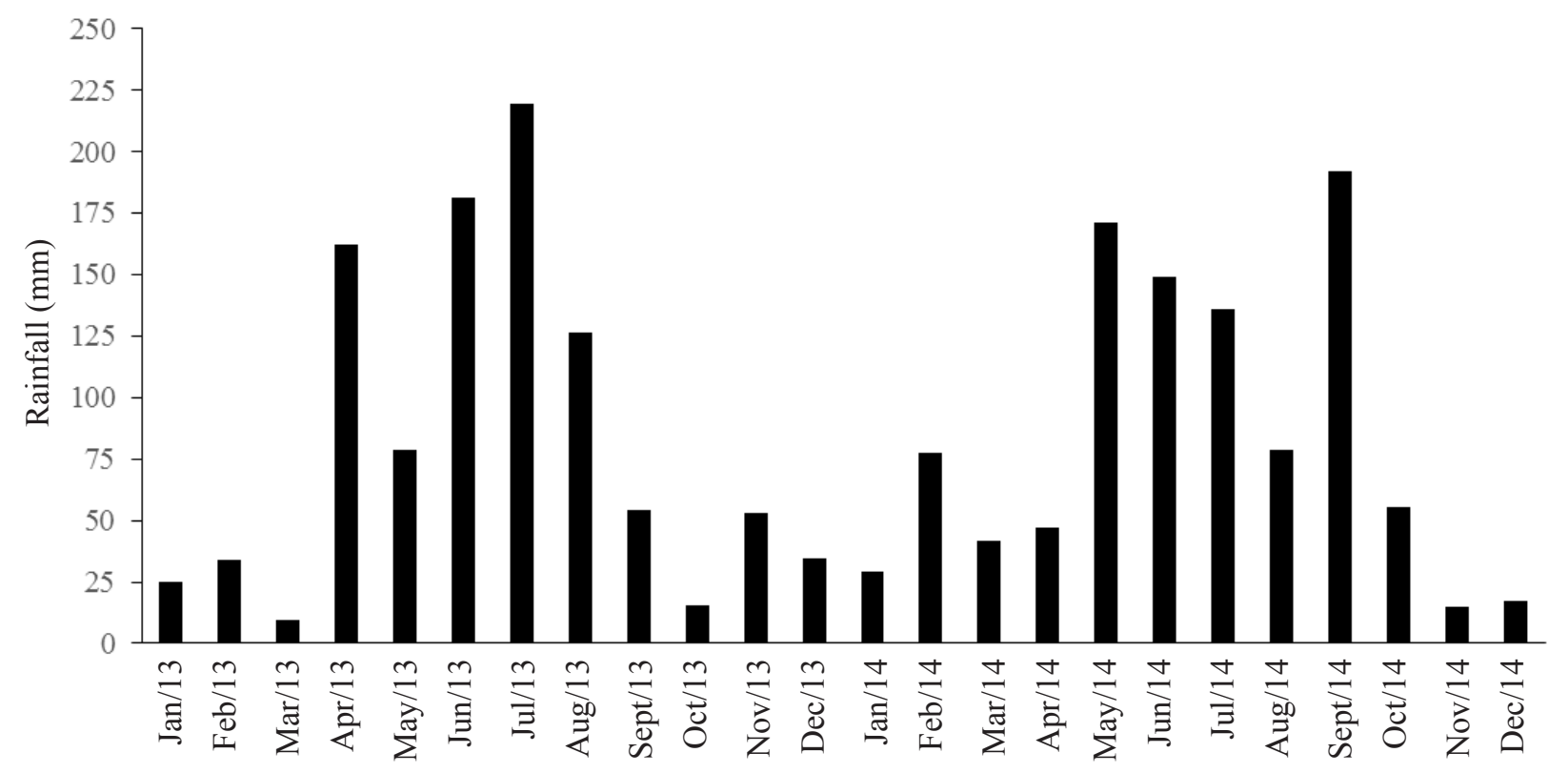

Agricultural months of the years 2013 and 2014

Figure 1. Rainfall in the experimental area in the agricultural years of 2013 and 2014 
Table 1. Chemical characteristics of soil in the cultivated area

\begin{tabular}{|c|c|c|c|c|c|c|c|c|c|c|c|}
\hline \multirow{2}{*}{$\begin{array}{l}\mathrm{pH}_{\mathrm{SP}} \\
1: 2.5\end{array}$} & $\mathrm{Ca}^{2+}$ & $\mathrm{Mg}^{2+}$ & $\mathrm{Na}^{+}$ & $\mathbf{K}^{+}$ & $S$ & $\mathrm{H}+\mathrm{Al}$ & $\mathbf{A l}^{3+}$ & $T$ & \multirow{2}{*}{$\begin{array}{l}\mathbf{V} \\
\%\end{array}$} & \multirow{3}{*}{ 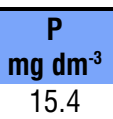 } & \multirow{3}{*}{$\begin{array}{c}\mathbf{O M} \\
\mathbf{g ~ k g}^{-1} \\
1.17\end{array}$} \\
\hline & \multicolumn{8}{|c|}{ Exchange complex $\left(\mathrm{mmol}_{\mathrm{c}} \mathrm{dm}^{-3}\right)$} & & & \\
\hline 5.3 & 5.6 & 3.5 & 3.8 & 1.8 & 14.7 & 16.3 & 2.0 & 31.4 & 48.8 & & \\
\hline
\end{tabular}

$\mathrm{S}$ - Sum of bases; $\mathrm{T}$ - Cation exchange capacity; $\mathrm{V}$ - Base saturation; $\mathrm{OM}$ - Organic matter; Methods of determination: $0 \mathrm{M}$ - Walkley-Black wet digestion; Ca ${ }^{2+}$ and $\mathrm{Mg}^{2+}$ extracted with 1 $\mathrm{mol} \mathrm{L-1} \mathrm{KCl}$ at $\mathrm{pH}$ 7.0; $\mathrm{Na}^{+}$and $\mathrm{K}^{+}$extracted using $1 \mathrm{~mol} \mathrm{~L}^{-1} \mathrm{NH}_{4} \mathrm{OAc}$ at $\mathrm{pH} 7.0 ; \mathrm{pH}_{\mathrm{SP}}-\mathrm{pH}$ of the saturation paste

evaluated in fully expanded and totally formed leaves of two plants per plot from 6 to 10 a.m. The selection of the times was based on the recommendations of Oliveira et al. (2005).

Data were collected on the fourth fully expanded leaf from the apex of the plant, below the inflorescence, with the IRGA - LCPro + (Analytical Development, Kings Lynn, UK), measuring the following parameters: $\mathrm{CO}_{2}$ assimilation rate $(\mathrm{A})$ ( $\mu \mathrm{mol}$ of $\mathrm{CO}_{2} \mathrm{~m}^{-2} \mathrm{~s}^{-1}$ ); internal $\mathrm{CO}_{2}$ concentration $(\mathrm{Ci})(\mathrm{mmol}$ of $\left.\mathrm{CO}_{2} \mathrm{~m}^{2}\right)$; transpiration (E) ( $\mathrm{mmol}$ of $\left.\mathrm{H}_{2} \mathrm{O} \mathrm{m}^{-2} \mathrm{~s}^{-1}\right)$ and stomatal conductance (gs) ( $\mathrm{mol}$ of $\left.\mathrm{H}_{2} \mathrm{O} \mathrm{m}^{-2} \mathrm{~s}^{-1}\right)$. The water use efficiency (WUE) $\left[\left(\mu \mathrm{mol} \mathrm{m} \mathrm{m}^{-2} \mathrm{~s}^{-1}\right)\left(\mathrm{mol} \mathrm{H}_{2} \mathrm{O} \mathrm{m}^{-2} \mathrm{~s}^{-1}\right)^{-1}\right]$ was obtained by the ratio between $\mathrm{CO}_{2}$ assimilation rate and transpiration (A/E) and the calculation of the $\mathrm{A} / \mathrm{Ci}$ ratio was used to obtain the instantaneous carboxylation efficiency (EICi) $\left[\left(\mu \mathrm{mol} \mathrm{m} \mathrm{m}^{-2} \mathrm{~s}^{-1}\right)\right.$ ( $\mathrm{mmol}$ of $\left.\mathrm{CO}_{2} \mathrm{~m}^{2}\right)^{-1}$ ] (Suassuna et al., 2014).

The SPAD index, which quantitatively evaluates the intensity of green color by measuring the transmissions of light from 650 to $940 \mathrm{~nm}$, was determined using the portable device SPAD- 502 (Soil Plant Analysis Development - Minolta Camera Co.), following the procedures adopted by Guimarães et al. (1999). The data were subjected to analysis of variance by F test and regression using the statistical program SISVAR-UFLA.

\section{Results AND Discussion}

Except for stomatal conductance (gs), which did not respond to the effects of any treatment, the interaction between planting densities and $\mathrm{N}$ doses caused significant effect on all physiological variables shown in Table 2 . The ideal is to search in the literature for studies of this nature or similar to compare the statistical behavior of the data. As to stomatal conductance, it would be more important to compare it first with data of non-irrigated cultivation and then with data of irrigation with saline water.

The $\mathrm{CO}_{2}$ assimilation rate data, except those referring to the dose of $40 \mathrm{~kg} \mathrm{ha}^{-1}$ of N -NF1 (Figure 2A), showed linear tendency, with increment of $0.0009 \mu \mathrm{mol}$ of $\mathrm{CO}_{2} \mathrm{~m}^{-2} \mathrm{~s}^{-1}$ for every increase in the number of plants per hectare. Among the $\mathrm{N}$ doses, the most efficient in $\mathrm{CO}_{2}$ assimilation rate was $80 \mathrm{~kg}$ $\mathrm{ha}^{-1}$ of N (NF3) associated with the maximum planting density of 2,250 plants ha ${ }^{-1}$, which led to the value of $4.45 \mu \mathrm{mol}$ of $\mathrm{CO}_{2}$ $\mathrm{m}^{-2} \mathrm{~s}^{-1}$. This result exceeds in 85.4 and $4 \%$, respectively, the lowest ( 833 plants ha ${ }^{-1}$ ) and highest (2500 plants ha ${ }^{-1}$ ) planting densities for this same $\mathrm{N}$ dose.

The results are lower than the value of $5.37 \mathrm{mmol} \mathrm{m}^{-2} \mathrm{~s}^{-1}$, found by Simões et al. (2014) evaluating the biometric and physiological parameters in the initial stage of jatropha. Freitas et al. (2012) suggest that the higher photosynthetic activity in the plants results from a more efficient photosynthetic apparatus, since $\mathrm{N}$ is a constituent of the chlorophyll and the RuBisCO enzyme, molecules that are essential for photosynthetic activity. The photosynthetic capacity of plants cultivated under adequate $\mathrm{N}$ supply is higher than that of plants cultivated under deficiency of this macronutrient (Pompelli et al., 2010).

According to the regression equations for the internal $\mathrm{CO}_{2}$ concentration $(\mathrm{Ci})$ during the flowering period (Figure $2 \mathrm{~B}$ ) as a function of planting densities and $\mathrm{N}$ doses, the linear model showed the best fit. In the treatments with $\mathrm{N}$ fertilization NF2, $\mathrm{NF} 3, \mathrm{NF} 4$ and NF5, there were reductions in the results of 0.0142 , $0.0174,0.0032$ and $0.0229 \mathrm{mmol}$ of $\mathrm{CO}_{2} \mathrm{~m}^{2}$, respectively, as the

Table 2. Summary of the analysis of variance and polynomial regression components for $\mathrm{CO}_{2}$ assimilation rate (A), internal $\mathrm{CO}_{2}$ concentration (Ci), transpiration (E), stomatal conductance (Gs), water use efficiency (WUE), instantaneous carboxylation efficiency (EICi) and SPAD index in jatropha plants cultivated at different planting densities and subjected to different nitrogen $(\mathrm{N})$ fertilization doses

\begin{tabular}{|c|c|c|c|c|c|c|c|c|c|}
\hline \multirow{2}{*}{\multicolumn{2}{|c|}{ Source of variation }} & \multicolumn{8}{|c|}{ Mean square } \\
\hline & & DF & $\mathbf{A}$ & $\mathbf{C i}$ & $E$ & Gs & WUE & EICi & SPAD index \\
\hline \multicolumn{2}{|l|}{ Block } & 3 & $0.781^{\mathrm{ns}}$ & $200.47^{\text {ns }}$ & $0.320^{\text {ns }}$ & $0.028^{\text {ns }}$ & $0.078^{\text {ns }}$ & $0.000002^{\text {ns }}$ & $0.640^{\text {ns }}$ \\
\hline \multicolumn{2}{|c|}{ Planting density (PD) } & 3 & $5.826^{* *}$ & $641.94^{\mathrm{ns}}$ & $0.187^{\mathrm{ns}}$ & $0.010^{\text {ns }}$ & $1.495^{\star *}$ & $0.000048^{\star \star}$ & $6.944^{*}$ \\
\hline \multicolumn{2}{|c|}{ Residual (a) } & 9 & 0.275 & 220.22 & 0.303 & 0.013 & 0.139 & 0.000005 & 1.561 \\
\hline \multicolumn{2}{|c|}{$\mathrm{N}$ fertilization (NF) } & 4 & $7.071^{* *}$ & $419.70^{\text {ns }}$ & $0.697^{\star *}$ & $0.0012^{\mathrm{ns}}$ & $2.728^{\star \star}$ & $0.000071^{* *}$ & $155.075^{\star *}$ \\
\hline \multicolumn{2}{|c|}{ PD x NF } & 12 & $2.153^{\star \star}$ & $579.24^{\star \star}$ & $0.602^{* *}$ & $0.010^{\text {ns }}$ & $0.690^{\star *}$ & $0.000026^{\star \star}$ & $8.557^{\star \star}$ \\
\hline \multicolumn{2}{|c|}{ Residual (b) } & 48 & 0.296 & 205.57 & 0.094 & 0.008 & 0.172 & 0.000004 & 0.953 \\
\hline \multicolumn{2}{|c|}{ CV (\%) a } & - & 14.12 & 4.47 & 29.87 & 62.25 & 21.42 & 22.93 & 2.71 \\
\hline \multicolumn{2}{|l|}{ CV (\%) b } & - & 14.75 & 4.32 & 18.68 & 49.19 & 23.84 & 20.94 & 2.11 \\
\hline \multirow{2}{*}{$\mathrm{PD} / \mathrm{NF} 1$} & LR & 1 & $5.509^{* *}$ & $897.139^{\star *}$ & $0.0199^{\text {ns }}$ & $0.016^{\mathrm{ns}}$ & $1.282^{\star \star}$ & $0.000144^{* \star}$ & $1.075^{\star *}$ \\
\hline & QR & 1 & $0.161^{\mathrm{ns}}$ & $82.82^{\text {ns }}$ & $0.0008^{\text {ns }}$ & $0.010^{\mathrm{ns}}$ & $0.239^{\text {ns }}$ & $0.000103^{*}$ & $1.485^{\mathrm{ns}}$ \\
\hline \multirow{2}{*}{ PD/NF2 } & LR & 1 & $9.036^{*}$ & $1315.85^{\star}$ & $0.1054^{\text {ns }}$ & $0.023^{\text {ns }}$ & $0.725^{\text {ns }}$ & $0.000124^{* *}$ & $8.475^{\star *}$ \\
\hline & QR & 1 & $6.038^{*}$ & $43.41^{\mathrm{ns}}$ & $0.037^{\mathrm{ns}}$ & $0.017^{\mathrm{ns}}$ & $0.259^{\text {ns }}$ & $0.000001^{\mathrm{ns}}$ & $4.197^{\star \star}$ \\
\hline \multirow{2}{*}{ PD/NF3 } & LR & 1 & $16.635^{\star \star}$ & $1462.72^{*}$ & $10.083^{\text {ns }}$ & $0.004^{\mathrm{ns}}$ & $25.85^{\star \star}$ & $0.000131^{* \star}$ & $4.010^{\star}$ \\
\hline & QR & 1 & $3.52^{\star}$ & $10.083^{\text {ns }}$ & $0.0102^{\text {ns }}$ & $0.003^{\text {ns }}$ & $9.93^{*}$ & $0.000036^{\text {ns }}$ & $5.766^{*}$ \\
\hline \multirow{2}{*}{ PD/NF4 } & LR & 1 & $5.113^{\star \star}$ & $29.84^{\mathrm{ns}}$ & $1.554^{*}$ & $0.010^{\text {ns }}$ & $0.0012^{\mathrm{ns}}$ & $0.000001^{\text {ns }}$ & $10.534^{\star \star}$ \\
\hline & QR & 1 & $2.870^{*}$ & $5.95^{\mathrm{ns}}$ & $1.218^{*}$ & $0.0003^{\text {ns }}$ & $0.0181^{\text {ns }}$ & $0.000014^{\mathrm{ns}}$ & $1.787^{\star}$ \\
\hline \multirow{2}{*}{ PD/NF5 } & LR & 1 & $1.597^{\star \star}$ & $1692.44^{\star *}$ & $0.596^{*}$ & $0.036^{\mathrm{ns}}$ & $0.168^{*}$ & $0.000000^{\text {ns }}$ & $10.289^{\star \star}$ \\
\hline & QR & 1 & $2.292^{*}$ & $7.52^{\text {ns }}$ & $0.407^{\star}$ & $0.010^{\mathrm{ns}}$ & $0.468^{*}$ & $0.000000^{\text {ns }}$ & $8.028^{*}$ \\
\hline
\end{tabular}

* Significant at 0.01; *Significant at 0.05; ns Not significant; LR - Linear regression; QR - Quadratic regression 


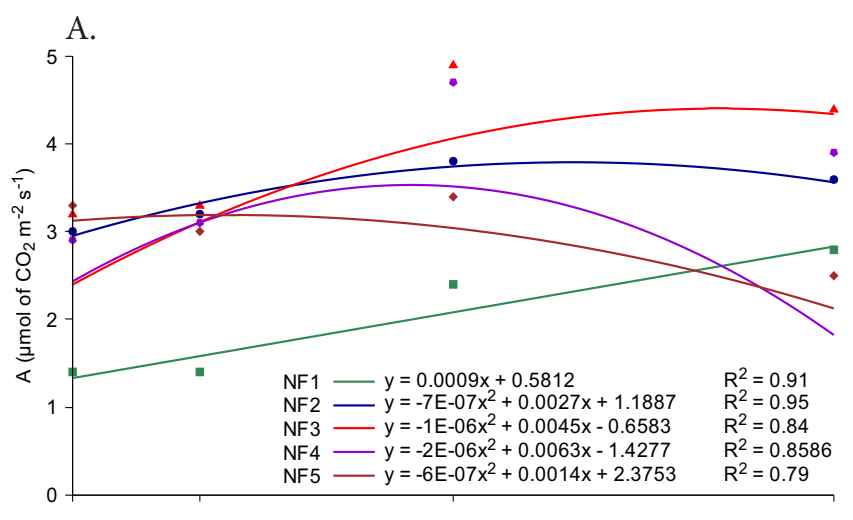

B.
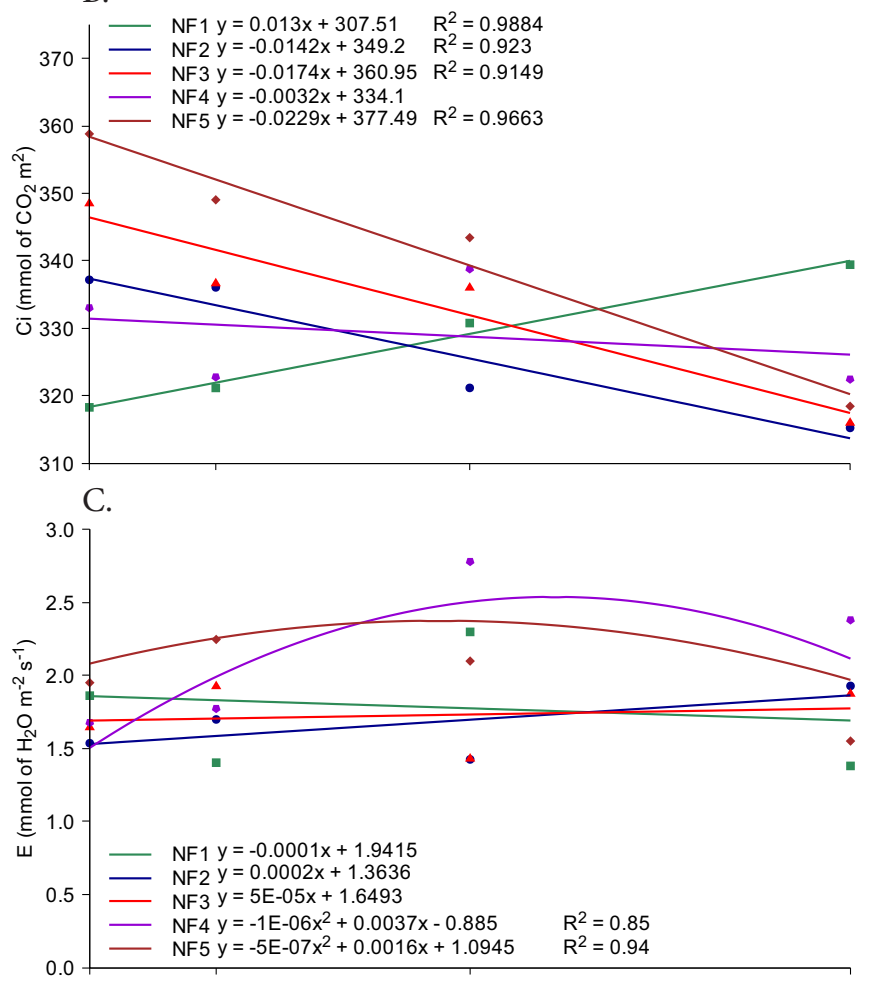

D.

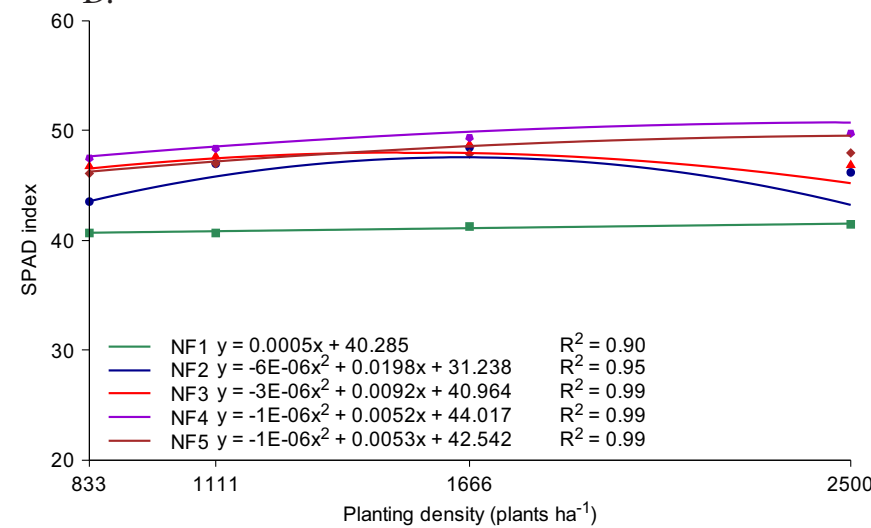

Figure 2. $\mathrm{CO}_{2}$ assimilation rate-A (A), internal $\mathrm{CO}_{2}$ concentration-Ci (B), transpiration-E (C) and SPAD index (D) of jatropha plants as a function of different planting densities and nitrogen fertilization doses

number of plants per hectare increased, with opposite response in relation to the treatment NF1. One of the explanations for this result is probably the increase in the competition between plants, since this treatment did not receive any $\mathrm{N}$.

The observed reductions in internal $\mathrm{CO}_{2}$ concentration reflect the decreases in $\mathrm{CO}_{2}$ assimilation rate, justifying the fact that, during the process of gas exchange, the absorption of $\mathrm{CO}_{2}$ causes water loss and, in the opposite direction, it favors a reduction in the $\mathrm{CO}_{2}$ assimilation, thus leading to lower internal $\mathrm{CO}_{2}$ concentration (Ferraz et al., 2014). The internal $\mathrm{CO}_{2}$ concentration depends on the climatic conditions and on the nutritional supply to the plants, both at planting and as top-dressing (Taiz \& Zeiger, 2013). Another factor, such as the genetic load of the plant, favors differences regarding the level of response to a certain factor, particularly the internal C concentrations.

The $\mathrm{CO}_{2}$ assimilation rate and transpiration are directly correlated, through the stomata, because, at the same time that the stomata offer resistance to water diffusion from the leaf to the atmosphere, they constitute a barrier for the acquisition of $\mathrm{CO}_{2}$ (Ferraz et al., 2012). According to Figure 2C, the regression equations for jatropha transpiration fitted to a quadratic model for the treatments NF4 and NF5, at the adopted planting densities, and the highest transpiration rate was observed for the $\mathrm{N}$ dose of $120 \mathrm{~kg} \mathrm{ha}^{-1}$, with maximum transpiration of 2.537 mmol of $\mathrm{H}_{2} \mathrm{O} \mathrm{m}^{-2} \mathrm{~s}^{-1}$ for the density of 1850 plants ha ${ }^{-1}$, surpassing in 62 and $20 \%$, respectively, the lowest ( 833 plants ha $\left.{ }^{-1}\right)$ and highest (2500 plants ha- ${ }^{-1}$ ) planting densities. These results are similar to the value of $2.48 \mathrm{mmol}$ of $\mathrm{H}_{2} \mathrm{O} \mathrm{m}^{-2} \mathrm{~s}^{-1}$ found by Sousa et al. (2012) in jatropha plants irrigated with wastewater and saline water, during the fourth year of production.

The chlorophyll in jatropha leaves, based on the SPAD index (Figure 2D), evidences the existing relationship with the $\mathrm{CO}_{2}$ assimilation rate and that, for the jatropha crop, the photosynthetic pigments are directly correlated. In this context, Engels \& Marschener (1995) comment that the $\mathrm{CO}_{2}$ assimilation rate must be proportional to the concentration of chlorophyll and that it is only valid for situations in which the concentration is below the optimal value for this process.

According to Figure 2D, the treatments with 40 (NF2), 80 (NF3) and $180 \mathrm{~kg} \mathrm{ha}^{-1}$ of N (NF5) promoted a maximum SPAD index of approximately 48 , which is only $4 \%$ inferior to that of the treatment with $120 \mathrm{~kg} \mathrm{ha}^{-1}$ of N (NF4), which was equal to 50 . The greater difference between the treatments indicates much more the influence of planting density than that of $\mathrm{N}$ fertilization, because the best combination was observed for the condition of $120 \mathrm{~kg} \mathrm{ha}^{-1}$ of N (NF4) and 2,450 plants ha-1.

The obtained results are within the range indicated by Freiberger et al. (2015), who mention that the SPAD index of 46 , measured in the first fully developed leaf from the apex, can be used as a nutritional reference of $\mathrm{N}$ in the initial development of the jatropha crop. The results are also in agreement with Possas et al. (2014), who obtained SPAD index of 47.7 in jatropha plants at 150 days after transplanting, under organic and phosphate fertilization.

The water use efficiency, expressed by the relationship between the $\mathrm{CO}_{2}$ assimilation rate and the transpiration, is associated with the amount of carbon that the plant fixes per unit of water transpired. According to the data of Figure 3A, the $\mathrm{N}$ dose of 80 (NF3) resulted in the highest WUE of 3.56 $\left[\left(\mu \mathrm{mol} \mathrm{m} \mathrm{m}^{-2} \mathrm{~s}^{-1}\right)\left(\mathrm{mol} \mathrm{H}_{2} \mathrm{O} \mathrm{m}^{-2} \mathrm{~s}^{-1}\right)^{-1}\right]$ at the planting density of 2,050 plants ha ${ }^{-1}$. Comparatively, this result surpasses in 7 and $71.7 \%$, respectively, those obtained in plants at the highest and lowest planting density. 

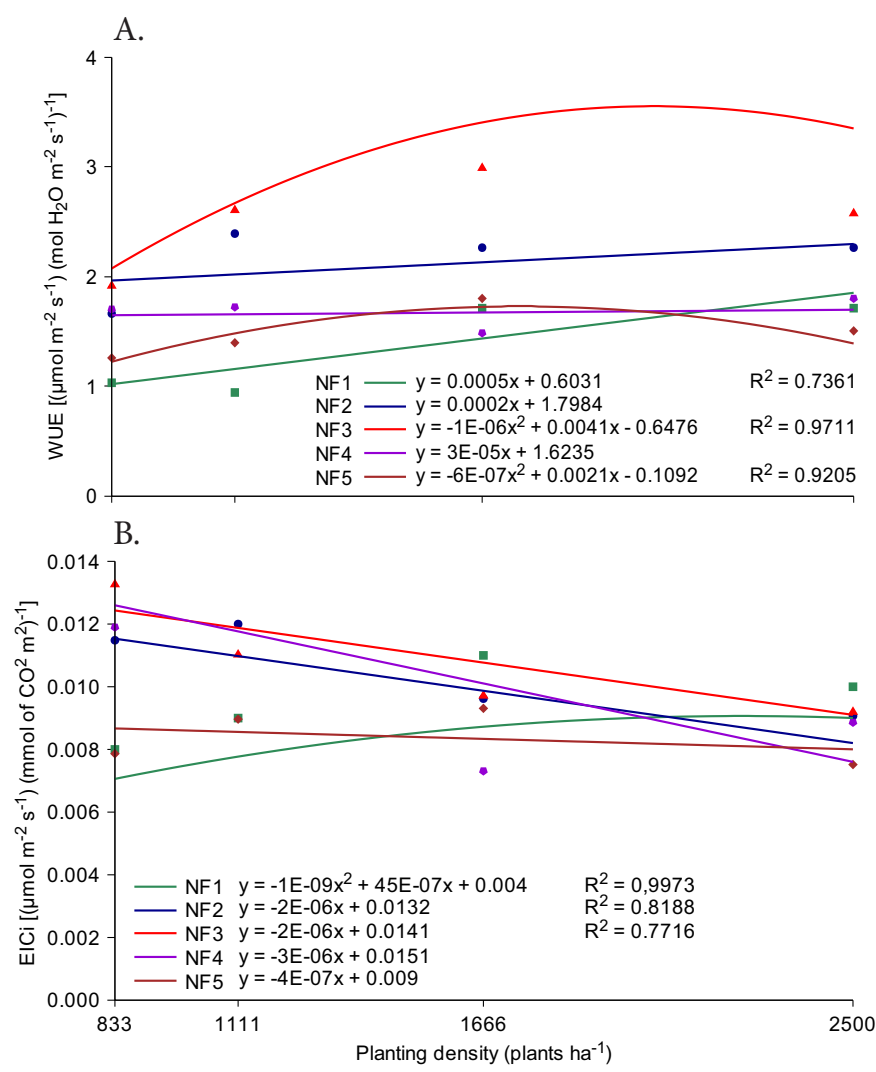

Figure 3. Water use efficiency-WUE (A), instantaneous carboxylation efficiency-EICi (B) of jatropha plants as a function of the interaction between different planting densities and nitrogen fertilization doses

The instantaneous carboxylation efficiency (EICi) is the relationship used to study the non-stomatal factors that interfere with the photosynthetic rate and is related to the net photosynthetic rate and $\mathrm{CO}_{2}$ concentration inside the substomatal chamber (Suassuna et al., 2014). According to Figure 3B, the treatments NF2 and NF3 showed similar values, as well as a similar decrease in their values, a reduction of $0.000002\left[\left(\mu \mathrm{mol} \mathrm{m}{ }^{-2} \mathrm{~s}^{-1}\right)\left(\mathrm{mmol} \text { of } \mathrm{CO}_{2} \mathrm{~m}^{2}\right)^{-1}\right]$ for every increase in planting density. The derivation of the equation of the treatment with $0 \mathrm{~kg} \mathrm{ha}^{-1}$ of N (NF1) theoretically results in an EICi of $0.0096\left[\left(\mu \mathrm{mol} \mathrm{m}^{-2} \mathrm{~s}^{-1}\right)\left(\mathrm{mmol} \text { of } \mathrm{CO}_{2} \mathrm{~m}^{2}\right)^{-1}\right]$ for a maximum population of 2,250 plants $\mathrm{ha}^{-1}$. According to the results for the highest planting densities, the values of all treatments tend to approximately $0.010\left[\left(\mu \mathrm{mol} \mathrm{m}^{-2} \mathrm{~s}^{-1}\right)(\mathrm{mmol}\right.$ of $\left.\mathrm{CO}_{2} \mathrm{~m}^{2}\right)^{-1}$. For Soares et al. (2012), the instantaneous carboxylation efficiency is mainly due to the increments in internal $\mathrm{CO}_{2}$ concentration and the gains in the $\mathrm{CO}_{2}$ assimilation rate, which was also observed in the behavior of the data for jatropha in the present study.

\section{Conclusions}

1. The use of different doses of nitrogen fertilization and planting densities directly influences the physiological aspects of jatropha, with a maximum point for $\mathrm{CO}_{2}$ assimilation rate, internal $\mathrm{CO}_{2}$ concentration, transpiration, water use efficiency, instantaneous carboxylation efficiency and SPAD index.

2. The use of nitrogen fertilization for the jatropha crop at the dose of $80 \mathrm{~kg} \mathrm{ha}^{-1}$ of $\mathrm{N}$, associated with the density of
2,200 plants ha ${ }^{-1}$, promotes higher $\mathrm{CO}_{2}$ assimilation rate and water use efficiency.

\section{Literature Cited}

Akbarian, M. M.; Modafebehzadi, N.; Bagheripour, M. A. Study of fertilizer (NPK) effects on yield and triglycerids in Jatropha (Jatropha curcas). Plant Ecophysiology, v.2, p.169-172, 2010.

Bangzhen, P.; Zengfu, X. Benzyladenine treatment significantly increases the seed yield of the biofuel plant Jathopha curcas. Journal of Plant Growth Regulation, v.30, p.166-174, 2011. http:// dx.doi.org/10.1007/s00344-010-9179-3

Brito, S.; Araújo, J. M.; Costa, A. S.; Silva, L. A.; Viégas, R. A. Crescimento inicial de Jatropha curcas L. em resposta a diferentes substratos e fontes nitrogenadas. Revista Agrotecnologia, v.5, p.50-68, 2014.

Engels, C.; Marschener, H. Plant uptake and utilization of nitrogen. In: Bacon, E. P. (ed.) Nitrogen fertilization in the environment. New York: Marcel Deker, 1995. p.41-71.

Ferraz, R. L. S.; Beltrão, N. E. de M.; Melo, A. S. de; Magalhães, I. D.; Fernandes, P. D.; Rocha, M. S. Trocas gasosas e eficiência fotoquímica de cultivares de algodoeiro herbáceo sob aplicação de silício foliar. Semina: Ciências Agrárias, v.35, p.735-748, 2014. http://dx.doi.org/10.5433/1679-0359.2014v35n2p735

Ferraz, R. L. S.; Melo, A. S. de; Suassuna, J. F.; Brito, M. E. B.; Fernandes, P. D.; Nunes Júnior, E. S. Trocas gasosas e eficiência fotossintética em ecótipos de feijoeiro cultivados no semiárido. Revista Pesquisa Tropical, v.42, p.181-188, 2012. http://dx.doi. org/10.1590/S1983-40632012000200010

Freiberger, M. B.; Guerrini, I. A.; Castoldi, G.; Favare, L. G. Soil fertility, nutrition and early growth of physic nut as affected by nitrogen fertilization. Journal of Plant Nutrition, v.38, p.13091322, 2015. http://dx.doi.org/10.1080/01904167.2014.983120

Freitas, R. G.; Araujo, S. F.; Matos, F. S.; Missio, R. F.; Dias, L. A. Desenvolvimento de mudas de pinhão manso sob diferentes doses de nitrogênio. Revista Agrotecnologia, v.3, p.24 -35, 2012. http:// dx.doi.org/10.12971/2179-5959.v03n02a03

Guimarães, T. G.; Fontes, P. C. R.; Pereira, P. R. G.; Alvarez V., V. H.; Monnerat, P. H. Teores de clorofila determinados por medidor portátil e sua relação com formas de nitrogênio em folhas de tomateiro cultivado em dois tipos de solo. Bragantia, v.58, p.209216, 1999. http://dx.doi.org/10.1590/S0006-87051999000100020

Horschutz, A. C. O.; Teixeira, M. B.; Alves, J. M.; Silva, F. G.; Silva, N. F. Crescimento e produtividade do pinhão-manso em função do espaçamento e irrigação. Revista Brasileira de Engenharia Agrícola e Ambiental, v.16, p.1093-1099, 2012. http://dx.doi. org/10.1590/S1415-43662012001000009

Laviola, B. G.; Alves, A. A.; Gurgel, F. L.; Rosado, T. B.; Costa, R. D.; Barros, R. R. Estimate of genetic parameters and predicted gains with early selection of physic nut families. Ciência e Agrotecnologia, v.36, p.163-170, 2012. http://dx.doi.org/10.1590/ S1413-70542012000200004

Mohapatra, S.; Panda, P, K. Effects of fertilizer application on growth and yield of Jatropha curcas L. in an Aeric Tropaquept of Eastern India. Natulae Scientia Biologicae, v.3, p.95-100, 2011.

Oliveira, A. D. de; Fernandes, E. J.; Rodrigues, T. J. D. Condutância estomática como indicador de estresse hídrico em feijão. Engenharia Agrícola, v.25, p.86-95, 2005. http://dx.doi.org/10.1590/ S0100-69162005000100010 
Pompelli, M. F.; Martins, S. C. V.; Celin, E. F.; Ventrella, M. C.; Damatta, F. M. What is the influence of ordinary epidermal cells and stomata on the leaf plasticity of coffee plants grown under fullsun and shady conditions? Brazilian Journal Biology, v.70, p.10831088, 2010. http://dx.doi.org/10.1590/S1519-69842010000500025

Possas, J. M. C.; Lima, R. L. S.; Nascimento, R.; Azevedo, C. A. V. de; Silva, A. A. R. Índice SPAD e inflorescência em plantas de pinhão manso submetidos à adubação orgânica e fosfatada. Revista Educação Agrícola Superior, v.29, p.37-40, 2014. http://dx.doi. org/10.12722/0101-756X.v29n01a10

Sharma, P. K. Effect of spacing on seed production and oil percentage of Jatropha curcas L. International Journal of Plant Sciences, v.7, p.63-64, 2012.

Simões, W. L.; Drumond, M. A.; Guimarães, M. J. M.; Oliveira, A. R.; Ferreira, P. P. B.; Souza, M. A. Desenvolvimento inicial e respostas fisiológicas do pinhão manso (Jatropha curcas L.) a diferentes lâminas de irrigação e doses de nitrogênio. Revista Brasileira Biociência, v.12, p.188-195, 2014.
Soares, L. A. A.; Sousa, J. R. M.; Brito, M. E. B.; Andrade, E. M. G.; Sá, F. V. S.; Silva, E. C. B. Influência de diferentes lâminas de irrigação nas trocas gasosas do tomateiro. Agropecuária Científica no Semiárido, v.8, p.118-122, 2012.

Sousa, A. E. C.; Silveira, J. A. G.; Gheyi, H. R.; Lima Neto, M. C.; Lacerda, C. F. de; Soares, F. A. L. Trocas gasosas e conteúdo de carboidratos e compostos nitrogenados em pinhão-manso irrigado com águas residuária e salina. Pesquisa Agropecuária Brasileira, v.47, p.1428-1435, 2012. http://dx.doi.org/10.1590/ S0100-204X2012001000003

Suassuna, J. F.; Fernandes, P. D.; Brito, K. S. A.; Nascimento, R.; Melo, A. S.; Brito, M. E. Trocas gasosas e componentes de crescimento em porta-enxerto de citros submetidos à restrição hídrica. Irriga, v.19, p.464-477, 2014. http://dx.doi.org/10.15809/ irriga.2014v19n3p464

Taiz, L.; Zeiger, E. Fisiologia vegetal. 5.ed. Porto Alegre: Artmed, 2013. 918p. 